\title{
Haastatteluja aika- ja kulttuurirajojen yli Valko-Venäjän kommunistisen järjestönuoruuden muistelukontekstissa
}

\author{
Kristiina Silvan
}

Haastattelija: Miksi [Komsomol-kokouksissa] kaikki aina äänestivät päätöslauselman puolesta?

Haastateltava: No koska... on sellainen sanonta, do feni. Tiedättekö? Do feni... tai do lampotški. Se tarkoittaa, että kaikille oli yhdentekevää

Haastattelija: Siinä tapauksessahan olisi hyvin voinut äänestää myös vastaan.

Haastateltava: Ei, koska muuten olisivat alkaneet kaikenlaiset välienselvittelyt. Sitäkö olisin halunnut? [nauraa] En suinkaan! Kysykääpäs Alekseilta, mitä "kaikille oli do lampotški" tarkoittaa. Aleksei vastaa, että "Komsomolissa kaikille oli do lampotški." Voi olla, että joku uskoi siihen kaikkeen. En tiedä. Itse en sellaisia tavannut.

(Haastattelu, 28.4.2017.)

Globaalissa maailmassa tutkijoiden tutkimuskentällä ei tunnu olevan rajoja. Myös muistitietotutkimuksen kohdalla tutkijoiden katse suuntautuu usein oman kieli- ja kulttuurialueen rajojen ulkopuolelle (ks. esim. Fraser 1986; James 2000; Leydesdorff 2011). Kysyn tässä katsauksessa, millaisia haasteita ja mahdollisuuksia monikulttuurinen konteksti tuo mukanaan muistitiedollisia metodeja hyödyntävän tutkimusprojektin haastatteluihin. Missä määrin haastattelutilanteen dynamiikassa vaikuttavat universaalit seikat kuten ikä, sukupuoli ja yhteiskuntaluokka; missä määrin puolestaan kulloinkin käsillä olevasta ylikulttuurisesta kontekstista nousevat erityistekijät?

Katsaukseni tarkoituksena on avata uusia näkökulmia muistitietotutkimukseen ylikulttuurisessa kontekstissa. Sen empiirisenä pohjana toimii kahdentoista muistitietohaastattelun kokonaisuus, jonka olen kerännyt Valko-Venäjällä keväällä 2017 osana väitöskirjatutkimustani. Näiden historiallisten muistitietohaastattelujen tarkoituksena oli kartoittaa neuvostoaikaisen kommunistisen nuorisoliiton eli Komsomol-järjestön jokapäiväistä toimintaa, "arkipäivän komsomolismia", yliopistokontekstissa niin sanotulla pitkällä 1970-luvulla'.

$1 \quad$ Neuvostoliiton historia voidaan jakaa erilaisiin aikakausiin, yleensä joko silloin maata johtaneen valtionpäämiehen tai jonkin sille ajalle tyypillisenä pidetyn piirteen mukaan. Tämän artikkelin tarkastelemaa aikakautta (1965-1985) on kutsuttu aiemmassa kirjallisuudessa Brežnevin (valtion päämies 1962-1982) aikakaudeksi, pysähtyneisyyden tai stagnaation ajaksi sekä pitkäksi 1970-luvuksi. Eräässä artikkelissaan jälkimmäistä termiä usein käyttävä politiikan tutkija Vladimir Gel'man määrittelee pitkän 1970-luvun tarkoittavan vuosiväliä 1968-1985 (Gel'man 2015, 12). Käytän tässä 
Aineistoon tuo oman erityisyytensä se, että haastateltavat muistelevat kommunistisessa yhteiskunnassa vietettyä nuoruuttaan 25 vuotta Neuvostoliiton hajoamisen jälkeen. Minun, haastattelijan, ja poliittisessa nuorisoliitossa toimineiden haastateltavien välillä on siis kaksinkertainen alueellinen ja ajallinen raja: neuvostoajan Valko-Venäjältä nykyajan Valko-Venäjälle, ja nyky-Valko-Venäjältä nyky-Suomeen.

Vaikka uskoin olevani hyvin valmistautunut haastattelutilanteeseen ja haastattelut suoritettiin haastateltavien äidinkielellä (venäjäksi), useat haastateltavat sanoivat suoraan tai vihjasivat, että nuoren ikäni ja eri kulttuuritaustani takia minun on mahdotonta ymmärtää tutkittavaa aihetta. Tämä näkyy myös katsauksen aloittavassa sitaatissa, jossa haastateltava olettaa ettei hänen käyttämänsä termi kieli- ja kulttuurisyistä avaudu haastattelijalle. Koska haastattelutilanteeni metodologisena lähtökohtana oli Alessandro Portellin $(2006,61)$ ja monien muiden muistitietotutkijoiden näkemys haastattelusta haastattelijan ja haastateltavan yhteistyön lopputuloksena, on minun ja kertojieni väliin aukeavan kuilun pohtiminen tutkimukseni kannalta oleellista. Millaisessa kontekstissa haastateltavat ilmaisivat että välillämme oli kulttuurinen kuilu ja mikä heitä saattoi motivoida? Entä miten minun tulisi tutkijana reagoida tilanteisiin, joissa kuilu tuntui olevan läsnä?

Katsaus on keskustelunavaus myös niille muistitietotutkimuksen metodeja käyttäville tutkijoille, joiden haastattelukontekstiin monikulttuurisuus ei kuulu. Pyrkimykseni onkin haastaa muistitiedon kerääjiä olemaan entistä reflektiivisempiä myös haastattelutilanteissa, joissa haastattelijan ja haastateltavan väliset rajat ja kuilut eivät välttämättä ole ilmiselviä ja joissa niitä ei sanallisteta. Uskon, että tietoisuus erilaisista rajoista auttaa tulkitsemaan tuotettua aineistoa sensitiivisemmin, mikä tekee tutkijoista myös parempia haastattelijoita. Haastattelutilanteiden ja haastattelujen sisällön pohtiminen esimerkiksi kenttätyöpäiväkirjassa etnografien tapaan onkin mielestäni hyvä tapa oppia reflektiivisyyttä. (Haastattelupäiväkirjasta ks. Koivunen ja Teräs 2017, 204.) Viittaan tässä katsauksessa haastattelujen ohella myös omiin kenttäpäiväkirjamerkintöihini.

Katsaukseni koostuu neljästä osasta. Esittelen ensin lyhyesti haastattelujeni aiheen, Neuvostoliiton kommunistisen nuorisoliiton, sekä sitä ja neuvostonuoruutta koskevan aikaisemman tutkimuskirjallisuuden. Tämän jälkeen esittelen aineistoni historiallisten muistitietohaastattelujen yhteydessä. Kolmas osio pureutuu monikulttuurisessa kontekstissa kerätyn muistitietoaineiston erityisyyteen, neljäs osio puolestaan niihin universaaleihin aspekteihin, jotka nousivat syystä tai toisesta tutkimuksessani vahvasti esille. Yhteenvedossa pohdin, millaista tietoa kieli- ja kansallisuusrajat ylittävä muistitietotutkimus tuottaa.

\section{Kommunistinen nuorisoliitto Komsomol Brežnevin ajan Valko-Venäjällä}

Valko-Venäjän sosialistinen neuvostotasavalta oli osa Neuvostoliittoa vuodesta 1922 vuoteen 1991. Marxismi-leninismin oppien mukaan yhteiskunnassa vaikuttivat kommunistisen puolueen alaisuudessa toimivat joukkojärjestöt. Lasten ja nuorten ideologiseen kasvatukseen panostettiin, ja koulujen ja perheen osalla merkittävässä roolissa olivat lapsi-ja nuorisojärjestöt. Tämän artikkelin keskiössä on Leninin kommunistinen nuorisoliitto (Leninskij kommunistitšeskij sojuz molodježi, lyhennettynä Komsomol), jonka jäsenet olivat 14-30-vuotiaita

katsauksessa pääasiassa termejä "myöhäinen neuvostoaika" sekä "pitkä 1970-luku", sillä ne ovat tekstini teeman huomioiden muita vaihtoehtoja parempia. 
(koulun 8. luokasta ylöspäin). Täysi-ikäisyyden saavutettuaan neuvostokansalaiset voivat hakea kommunistisen puolueen jäsenyyttä, jolloin osallistuminen lapsi- ja nuorisojärjestötoimintaan oli merkittävä jäsenyyttä puoltava tekijä. (Riordan 1989.)

Komsomol oli sen perustamisajankohtana 1920-luvun alussa nuorten kommunistien etujoukko, johon kuului vain pari prosenttia koko maan nuorisosta. Sen jäsenmäärä kuitenkin kasvoi tasaisesti seuraavien vuosikymmenten aikana, ja 1960-luvun aikana siitä muodostui koko nuorison kattava massajärjestö. Tämä oli seurausta sen yhteiskunnallisen tehtävän tarkentumisesta valtion ja kommunistisen puolueen kannalta: Komsomolin oli määrä kasvattaa nuoresta sukupolvesta kuuliaisia neuvostokansalaisia. Liitto olikin eräänlainen kommunistinen vaihtoehto partioliikkeelle, ja sen tavoitteena oli "uuden neuvostoihmisen" luominen. Näin ollen Komsomolin toiminnan piiriin piti sisällyttää myös kommunistiseen ideologiaan välinpitämättömästi suhtautuvat nuoret. Jäsenmäärän oletettiin kasvavan vuosi vuodelta tuotantotaloudellisten indikaattoreiden tavoin, ja siitä raportoitiin puolueelle säännöllisin väliajoin. (Riordan 1989; Pilkington 2002, 31-63.)

Vaikka Vladimir Lenin oli puhunut 1920-luvulla Komsomolin autonomian puolesta, oli järjestö muiden neuvostoliittolaisten rakenteiden tavoin täysin kommunistisen puolueen ohjailema. Komsomol ei ollut nuorten itsensä johtama järjestö, vaan johto koostui lähes poikkeuksetta puolueen jäsenistä. Komsomol toteutti lähinnä puolueen ja ministeriöiden sille delegoimia tehtäviä, eikä itse suunnitellut toimintaansa. (Riordan 1989.)

Vaikka lähes kaikki neuvostonuoret liittyivät yläkouluiässä Komsomoliin käytännössä automaattisesti, jäsenyyttä hakevien piti valmistautua opiskelemalla Neuvostoliiton poliittisen järjestelmän perusteet ja Komsomolin säännöt (Isaikina 2011; Kozlova 2008). Siitä huolimatta, että Komsomol-jäsenyys oli virallisesti vapaaehtoista, oli se käytännössä välttämätöntä etenkin niille oppilaille, jotka halusivat jatkaa opiskelua yliopistossa tai ammattikorkeakoulussa. Jäsenyyttä jopa oletettiin - siitä tietoisesti kieltäytyminen herätti epäilyjä nuoren poliittisesta lojaaliudesta, mikä lähes poikkeuksetta hankaloitti elämää puoluevaltiossa. Tilanteesta seurasi, että kommunistisesta ideologiasta tuli Komsomolin sisällä toisarvoista. Oleellista oli yksilön julkinen käytös ja puheet, ei se, mitä tämä tosiasiassa ajatteli. 1980-luvun lopulla, perestroikan ajalla sensuurin hellittäessä Komsomoliin kohdistuikin ennennäkemätön kritiikin aalto. (Tkachenko 2011, 97; Mironenko 2000; Yurchak 2006.)

Komsomolin jäsenet voitiin myöhäisellä neuvostoajalla jakaa kolmeen eri kategoriaan. Passiiviset rivijäsenet suorittivat liiton jäsenyyden minimivaatimukset: he maksoivat jäsenmaksut sekä osallistuivat kuuntelijan asemassa pakollisiin luentoihin, kokouksiin ja mielenosoituksiin. Aktiivijäsenet toimivat johtotehtävissä ruohonjuuritasolla ja osallistuivat aktivisteille järjestetyille kesäleireille ja kokouksiin. Kolmas ja pienin ryhmä Komsomolin jäsenistä toimi nuorisoliiton palkattuina työntekijöinä. Monille näistä työ Komsomolissa oli järjestötasosta riippuen askel valtionhallinnon uralla. Näiden tehtäviin kuului Komsomolin toiminnan suunnittelu ja toteutus sekä monenlainen toimistotyö. Periaatteessa alemman tason Komsomol-jäsenet valitsivat sekä aktivistit että palkatut työntekijät vaaleilla, mutta käytännössä puolue ja ylemmän tason Komsomol-komitea nimesivät heidät. (Riordan 1989; Yurchak 2006, 85-93.) 


\section{Valkovenäläisten Komsomol-jäsenten historiallinen muistitietohaastattelu}

Penny Summerfieldin (2004) jaottelun mukaan historiantutkijat käyttävät muistitietoaineistoa kolmella tavalla: perinteisesti, sosiaalihistoriallisesti ja kulttuurisesti. Perinteisen lähestymistavan mukaan muistitieto on niin subjektiivista, että sitä tulisi käyttää vain osana monipuolisempaa aineistokokonaisuutta. Myös sosiaalihistoriallisesta näkökulmasta muistitietoa hyödyntävät tutkijat suosivat aineiston triangulaatiota ja laajoja aineistokokonaisuuksia historiallisesti todenmukaisen kuvan takaamiseksi (Summerfield 2004, 65-66). Kulttuurinen muistitietotutkimus puolestaan painottaa muistitiedon suhdetta nykyhetkeen: muistelu on menneisyyden tarkastelua nykyisyyden ja kerrontatilanteen lähtökohdista. Tämän takia suuntauksen muistitietotutkijoille menneisyyden ja nykyisyyden välinen jännite ja se, miten menneisyyden tapahtumat kerrotaan, onkin usein yhtä kiinnostavaa kuin muistot itsessään (Summerfield 2004, 66-69; Ukkonen 2006, 187). Koska oman tutkimukseni pohja on kulttuurisessa historian- ja muistitietotutkimuksessa, tämän katsauksen kohteena on ennen kaikkea menneisyyden ja nykyisyyden välinen jännite. Toisaalta tavoitteenani on valottaa myös tilanteita, joissa kulttuurinen ja perinteinen historian- ja muistitietotutkimus ajautuivat törmäyskurssille muistitietohaastattelun aikana.

Suuntausten välisistä eroista huolimatta tutkijat ovat yhtä mieltä siitä, että muistamiseen vaikuttavat lukemattomat tekijät. Muistitiedon muodostuminen riippuu vahvasti haastattelun kontekstista sekä haastattelijan ja haastateltavan välisestä vuorovaikutuksesta (ks. esim. Yow 2016). Kulttuurisesta näkökulmasta katsottuna onkin tärkeää tarkastella kerrontaa reflektiivisesti monen tekijän summana. Reflektiivisyys eli haastatteluun osallistuvien paikantuneisuuden sekä haastatteludynamiikan pohtiminen on etenkin kulttuurisen muistitietotutkimuksen lähtökohdista toimiville tutkijoille korvaamaton työkalu.

2010-luvun historiantutkimuksen kentällä eri aineistokokonaisuuksien yhdistely on suositumpaa kuin menneinä vuosikymmeninä, mikä on edesauttanut muistitietotutkimuksen nousua marginaaliasemasta osaksi tieteenalan valtavirtaa (Koivunen ja Teräs 2017, 193). Jorma Kalelan (2000) hedelmällisyyden käsite, joka on suoraan sidoksissa tutkimusongelmaan ja -kysymyksiin, liittyy oleellisesti historiantutkimuksen lähdekritiikkiin ja tapaan lähestyä aineistoa. Aineisto, esimerkiksi muistitietohaastattelut, voidaan näin ollen lukea kontekstista riippuen hedelmälliseksi, eikä sitä voida suoralta kädeltä määritellä huonoksi tai puutteelliseksi. Eri maiden historiantutkimuksen kentät eroavat kuitenkin toisistaan, mikä nousi oman valtio- ja kulttuurirajoja ylittävän tutkimukseni kohdalla selkeästi esiin.

Kaikille historiantutkijoille suuntauksesta riippumatta ajalla on muistitietohaastattelujen kontekstissa merkittävä asema. Koska menneisyydestä kerrotaan nykyisyyden hetkellä, saman asian muistelu voi olla erilaista eri aikoina. (Ks. esim. Allison 2004.) Tietoisuus sekä kerrontahetken että menneisyyden ajallisesta kontekstista on oleellinen osa tutkimusprosessia ja mahdollistaa tutkittavan aineiston onnistuneen tulkinnan. Tämä katsauksen esittelemän tutkimuksen kohdalla ajallisuudella oli erittäin suuri rooli, sillä tutkittava konteksti, "pitkän 1970-luvun" Neuvostoliitto, oli merkittävästi erilainen yhteiskunta kuin neuvostoajan jälkeinen nyky-Valko-Venäjä. Yhteiskuntajärjestyksen muutos 1980-luvun lopussa ja 1990-luvun alussa oli ollut äärimmäisen nopea ja kokonaisvaltainen, minkä takia kuilu menneisyyden ja nykyisyyden välillä tuntui valkovenäläisessä muistelukontekstissa selkeämmältä kuin tapauksissa, joissa yhteiskunta on muuttunut vähitellen. 
Aikaan sisältyy poliittinen ulottuvuus, joka on jokaisessa Neuvostoliitosta irtautuneessa maassa omanlaisensa. Haastatteluaineistossa olisivat mahdollisesti korostuneet toiset seikat, jos olisin Valko-Venäjän sijasta haastatellut entisiä Komsomolin jäseniä vaikkapa Virossa. Valko-Venäjällä on kommunismiin suhtauduttu vuodesta 1995 lähtien myönteisemmin kuin monessa muussa Neuvostoliitosta itsenäistyneessä maassa (Gherghina ja Klymenko 2012, 62-63). Tähän on vaikuttanut Aljaksandr Lukašenkan valinta presidentiksi ja tämän neuvostomyönteinen ja valkovenäläisen nationalismin vastainen politiikka (Shushkevich 2002). Myös neuvostohenkiset lasten ja nuorten joukkojärjestöjet rakennettiin uudelleen 1990luvun lopussa. Lukašenkan autoritäärisessä valtiossa julkinen keskustelu on rajoitettua ja vapaa media marginalisoitu, minkä takia monen muun aiheen ohella myöskään neuvostoaikaan liittyvistä kiistanalaisuuksista ei voida käydä avointa yhteiskunnallista keskustelua. (Toisen maailmansodan muistelukontekstista ks. Goujon 2009.)

Myös lapsuuden ja nuoruuden muisteluun liittyvät omat erityistekijänsä. Pirjo Korkiakangas on tutkinut lapsuuden muistamista Suomessa ja havainnut, että lapsuuden muisteluun liittyy usein nostalgiaa, varsinkin, jos nykyhetki mielletään epävarmaksi (Korkiakangas 2013, 29; ks. myös Korkiakangas 1996). Jos elämää nyky-Valko-Venäjällä verrataan "pysähtyneisyyden" ajan Neuvostoliittoon, jossa arkielämä ja vaikkapa työmarkkinat olivat hyvinkin ennalta arvattavia, Neuvostoliiton hajoamisen jälkeistä aikaa voidaan luonnehtia epävarmaksi. Lapsuuteen liitetään yleisesti myös viattomuus, joka tämän katsauksen aiheen kohdalla näkyi siinä, että haastatellut suhtautuivat kriittisesti poliittisen toiminnan sotkemiseen lapsuuteen. (Burman 1995.) Myös nuoruus saattaa herättää ihmisissä vahvan nostalgisia tunteita, mutta viattomuus ei liity siihen yhtä oleellisesti: nuoruutta kuvataan usein kaunistelematta, toisin kuin lapsuutta (Vehkalahti 2014, 79-81).

Tämä katsaus perustuu Valko-Venäjällä keväällä 2017 kerättyyn haastatteluaineistoon $(n=12)$, jossa kartoitin kommunistiseen nuortenliittoon liittyviä muistoja muistitietotutkimuksen keinoin. Haastattelujen tarkoituksena oli tuottaa uutta tietoa "arkipäivän komsomolismista" opiskelijaelämässä "pitkällä 1970-luvulla", minkä takia sen vastaajiksi valikoitui 1950-luvulla syntyneitä, yliopiston käyneitä valkovenäläisiä. Haastateltavia etsittiin sopivan syntymäajan ja korkeakoulutaustan perusteella pääasiassa lumipallomenetelmällä. Suurin osa haastateltavista työskenteli yliopiston historian tai yhteiskuntatieteiden laitoksilla opetustehtävissä. Haastattelujen määrään vaikutti kyllääntyminen eli saturaatio sekä kenttätyölle asetetut aikarajoitukset.

Henkilöistä, joita lähestyin, vain yksi kieltäytyi haastattelusta, perustellen päätöstään sillä, ettei halunnut keskustella kanssani kyseisestä aiheesta. Tulkitsin lyhyeksi jääneen sananvaihtomme perusteella, että hänen kieltäytymiseen vaikutti nimenomaan tutkimani aihe. (Ote kenttätyöpäiväkirjasta, 10.4.2017.) Useat muut olivat alun perin haluttomia tulemaan haastatelluiksi, mitä he perustelivat passiivisuudellaan järjestön toiminnassa, mutta suostuivat lopulta haastateltaviksi (ks. esim. Ote kenttätyöpäiväkirjasta, 4.4.2017). Haastateltavista seitsemän kuului Komsomolin passiivisiin rivijäseniin. Kolme voidaan luokitella aktivisteiksi, ja kaksi työskenteli yliopistosta valmistumisen jälkeen nuorisoliitossa. Näistä yhdelle työtehtävä oli loogista jatkoa yliopistoajan aktivismille, toiselle vain hyvä työpaikka, jonne hän päätyi oman kertomansa mukaan puolivahingossa (haastattelu, 16.5.2017).

Haastattelut olivat luonteeltaan puolistrukturoituja teemahaastatteluja (Hirsjärvi ja Hurme 2008, 47-48), joiden aihepiirinä olivat haastateltavan kokemukset ja ajatukset 
neuvostoaikaisen Komsomol-järjestön toiminnasta. ${ }^{2}$ Minulla oli käytössäni 22 kohdan venäjänkielinen kysymyslomake, jota en kuitenkaan seurannut orjallisesti. Omakohtaisen kerronnan tutkimukseen nojaava otteeni salli teeman laajemman käsittelyn, jossa muun muassa lapsuusmuistot nousivat vahvasti esiin. (Autobiografisesta muistitietotutkimuksesta ks. esim. James 2000.) Vaikka kyseinen aihe oli etukäteen määrittelemäni tutkimusfokuksen ulkopuolella, en haastattelijana pyrkinyt ohjaamaan kerrontaa kovalla kädellä, vaan annoin sen rönsyillä melko vapaasti. Valitsemani haastattelumenetelmän tarkoitus oli antaa haastateltaville tilaa rakentaa kertomuksensa vapaammin kuin jos olisin ohjannut haastattelua aktiivisemmin (ks. esim. Leavy 2011, 19).

\section{Muistitietotutkimusta yli kulttuurillisten ja ajallisten rajojen}

Ensimmäinen raja-aita, johon törmäsin tutkimuksessani, oli ero suomalaisen ja valkovenäläisen muistitietotutkimuskontekstin välillä. Vaikka nykyään voidaan puhua eräänlaisesta globaalista muistitietotutkimuksen lähestymistavasta, muistitietoa kerätään ja käytetään eri maissa, kulttuureissa ja tieteenaloilla eri tavoin (Thompson ja Bornat 2017, 71). Suomalaisessa historiantutkimuksessa muistitieto nousi 2000-luvulle tultaessa marginaaleista osaksi valtavirtaa (Kalela 2006, 67), eikä se enää herätä kummastusta historiantutkijoiden keskuudessa, vaikka kontekstista riippuen sen käyttöä lähdemateriaalina saatetaankin arvostella. ${ }^{3}$

Valko-Venäjällä muistitietotutkimuksella on sen sijaan edelleen marginaalinen asema. Tämä kävi ilmi siitä, että useat haastateltavat kommentoivat valitsemaani tutkimusotetta joko haastattelua ennen, sen aikana tai sen jälkeen. Yksi vastaaja esimerkiksi kehotti minua käyttämään lähdeaineistona Valko-Venäjän kansallisarkistossa säilytettävän kommunistisen puolueen mapin numero neljä materiaalia ja unohtamaan haastattelut (haastattelu, 24.4.2017). Erään toisen henkilön mukaan minun tulisi haastatella Komsomolin virallisia toimihenkilöitä, eikä suinkaan liiton tavallisia rivijäseniä, sillä "eiväthän he tiedä Komsomolista mitään!" (Haastattelu, 15.5.2017). Selitykseeni siitä, että tavoitteenani on tutkia nimenomaan arkipäivän komsomolismia, suhtauduttiin perinteiselle historiantutkimukselle tyypillisellä lähdekriittisyydellä: "Ihmisethän saattavat ladella mitä tahansa!" (Haastattelu, 24.5.2017). Analyysi, joka perustuisi tavallisten rivijäsenten kertomuksiin, olisi rajoittunut ja jopa mahdollisesti "vääristynyt", näin minulle selitettiin (ote kenttätyöpäiväkirjasta 29.5.2017).

Kenttätyöpäiväkirjassani päättelin, että haastateltavien varautuneisuuden takana voisi olla ainakin kaksi merkittävää tekijää (ote kenttätyöpäiväkirjasta, 18.4.2017). Ensinnäkin, koska monet haastateltavat työskentelivät yliopistolla opetustehtävissä, he olivat tottuneita neuvomaan opiskelijoita ja väitöskirjantekijöitä metodologiaan liittyvissä kysymyksissä. Toiseksi heillä oli tutkijoina jonkinlainen käsitys siitä, mitä muistitietotutkimus pitää sisällään ja millaisia aiheita se käsittelee Tämä käsitys perustui kuitenkin ennen kaikkea venäjänkieliseen muistitietotutkimukseen, joka on keskittynyt lähinnä Stalinin ajan suurten yhteiskunnallisten muutosten (kuten repression ja pakkokollektivisoinnin) tutkimukseen sekä toiseen maailmansotaan (Thompson ja Bornat 2017, 96-99). Tästä näkökulmasta ei liene yllättävää,

2 Kaikki haastattelut nauhoitettiin haastateltavien luvalla. Tein haastatteluhetkellä myös muistiinpanoja. Litteroinnissa käytin apuvälineenäni Atlas.ti -ohjelmaa. Sekä muistiinpanoissa että litteroiduissa teksteissä vastaajien henkilöllisyys on anonymisoitu. Kaikki tekstit ovat venäjänkielisiä. Tätä ja muita aineistoon perustuvia artikkeleita varten olen itse kääntänyt lainaukset muille kielille. Haastatteluaineistoa ei ole julkaistu eikä arkistoitu jatkokäyttöön, sillä en pyytänyt siihen haastateltavilta lupaa.

3 Eräs tuoreimmista tapauksista, Marjo Liukkosen väitöskirja Hennalan naismurhat (2018), herätti laajempaa yhteiskunnallista keskustelua muistitiedon hedelmällisyydestä (ks. esim. Lintunen ja Tikka 2018). 
että 1970-luvun tutkiminen saattoi tuntua heistä liian tuoreelta ja jopa "tylsältä" (haastattelu, 17.5.2017).

Muistitietohaastattelujen lisäksi keräsin aineistoa myös arkistolähteistä. Tavoitteenani oli eri aineistotyyppien yhdistämisen avulla tuottaa monipuolinen kuva Komsomol-järjestön arkipäiväisestä toiminnasta ja pohtia lähdekriittisesti eri aineistojen välisiä eroja. ${ }^{4}$ (Koivunen ja Teräs 2017, 193, 196.) Erilaisten aineistojen tutkiminen oli hedelmällistä, koska minulle kävi ilmi, että arkistomateriaalin ja haastattelumateriaalin väliset eroavaisuudet olivat huomattavia. Arkistomateriaalin perusteella Komsomolin toiminta oli huomattavasti monipuolisempaa kuin millaiseksi se piirtyi haastateltavien narratiiveissa. Arkistomateriaalissa esimerkiksi esitettiin Komsomolin jäsenten koulumenestystä ja kommunismitietoa mittaavan Leninin testin (Leninskij zatšot) olevan olennainen järjestön rivijäsenille, koska se piti suorittaa vuosittain. Haastattelutilanteessa kukaan ei kuitenkaan maininnut Leninin testiä, eivätkä ne, joilta siitä kysyin erikseen, muistaneet siitä mitään (esim. haastattelu, 15.5.2017). Joko testistä vain raportoitiin ilman sen todellista järjestämistä, mikä oli suhteellisen levinnyt käytäntö tuon ajan Komsomol-järjestöissä (Yurchak 2006, 100), tai siihen osallistuminen merkitsi haastateltaville niin vähän, etteivät he muistaneet sitä enää haastatteluhetkellä, 40 vuoden jälkeen. Arkistomateriaalissa korostunut kommunistinen ideologisuus ei myöskään tullut yhtä vahvasti ilmi haastatteluissa. Tämän saattavat selittää kaksi seikkaa. Ensinnäkin ideologialla oli keskeinen osa Komsomolin raportoinnissa, joten sitä korostettiin. Toiseksi useammilla vastaajilla tuntui olevan monimutkainen suhde kommunistiseen ideologiaan, minkä takia siitä puhuminen saattoi olla heille haastattelutilanteessa vaikeaa. Esimerkiksi yksi naisvastaaja kertoi uskoneensa kommunismiin, mutta tulleensa Neuvostoliiton hajottua kristinuskoon (haastattelu, 26.4.2017).

Ylikulttuurisiin tutkimustilanteisiin liittyy myös muita haasteita. Kohdallani yksi minua ja haastateltavia lähentävä tekijä oli se, että puhun, luen ja kirjoitan sujuvasti venäjää, joka oli haastateltavien äidinkieli. ${ }^{5}$ Haastattelujen tekeminen muulla kielellä, esimerkiksi englanniksi, ei edes olisi ollut mahdollista, sillä haastateltavista vain harva puhui venäjän ohella muita kieliä. Haastattelun kieli riippuu kuitenkin aina tilanteesta ja tutkimuskysymyksistä. Esimerkiksi Susan K. Burton haastatteli sujuvasta japanin kielen taidostaan huolimatta japanilaisia vastaajiaan englanniksi, mikä oli tutkimuksen kontekstissa perusteltua (Burton 2016, 225-231). Kielitaidon puuttuessa on mahdollista käyttää apuna tulkkia tai ulkoistaa haastatteluiden tekeminen jollekin paikalliselle tutkijalle, mutta tällaisiin asetelmiin liittyy usein merkittäviä haasteita (Pietilä 2010, 415-420). Haastateltavat olivat ilmeisesti vakuuttuneita kielitaidostani, koska sain lähinnä kehuja venäjän kielen tasostani. Vain yksi haastateltava varmisti, että osasin myös lukea venäjäksi (haastattelu, 5.4.2017). Haastattelu venäjäksi mahdollisti sellaisten Komsomolin toimintaan vastaajien mielestä olennaisesti liittyneiden termien käytön kuten "sanan ja teon välinen kuilu" tai "hangata silmälaseja"6 , joiden kääntäminen englanniksi olisi mahdollisesti tuottanut hankaluuksia.

Haastattelutilanteessa kieltä merkittävämmäksi tekijäksi nousikin kulttuurien välinen kuilu. Ilkka Pietilä toteaa osuvasti: "Haastateltavan kannalta, erityisesti silloin, kun haastattelut

\footnotetext{
4 Komsomolia koskevaa materiaalia löytyykin runsaasti, sillä raportoinnilla oli merkittävä osa järjestön toiminnassa, ja raportteja tuotettiin järjestön jokaisella tasolla virallisen kaavan mukaisesti (ks. esim. Yurchak 2006, 100-103).

5 Valko-Venäjällä sekä valkovenäjällä että venäjällä on virallinen asema. Suurin osa etenkin urbaanista ja koulutetusta väestöstä suosii jokapäiväisessä kielenkäytössään venäjää, niin myös kaikki tämän tutkimuksen haastateltavat. Ven. razriv meždu slovom i delom sekä otški stirat'.
} 
käsittelevät oman maan asioita ja yhteiskunnallisia ilmiöitä, ulkomaalaiselle tutkijalle puhuminen tuottaa väistämättä tilanteen, jossa haastateltava toimii ikään kuin oman maansa ja kulttuurinsa edustajana" (Pietilä 2010, 415). Oman tutkimukseni kontekstissa ajatus edustamisesta tuli esiin hämmästelevissä kysymyksissä siitä, miksi suomalaisia kiinnostaa tutkimani aihe.? Haastateltavat saattoivat myös ehdottaa, että haastateltavaksi sopisi ehkä joku "itseä edustavampi" henkilö. Samoin osa haastateltavista kertoi Komsomol-järjestöstä huomattavasti innokkaammin yleisellä tasolla luennoiden kuin oman kokemuksensa kautta (haastattelu, 11.4.2017). Haastateltavat saattoivat vaikuttaa jopa yllättyneiltä kun kysyin heidän henkilökohtaisista kokemuksistaan (esim. haastattelu, 5.4.2017).

Myös se, ettei minulla ollut henkilökohtaista kokemusta neuvostoyhteiskunnasta, tuntui arveluttavan joitain haastateltavista. Tämä kävi ilmi tilanteissa, joissa haastateltava epäili tuntemustani neuvostoyhteiskunnasta - tai joissain tapauksissa kyseenalaisti mahdollisuuteni ymmärtää neuvostoliittolaisia arkielämän realiteetteja. Monet haastateltavat suosittelivat minulle Neuvostoliittoa ja etenkin Komsomolia käsittelevää kirjallisuutta ja elokuvia (esim. haastattelut 26.4.2017, 15.5.2017 ja 16.5.2017). Toisinaan tunsin, että vastaajat pitivät tarkentavia kysymyksiäni naurettavina. Esimerkiksi erään jälkeenpäin kenttätyöpäiväkirjassani "katastrofaaliseksi" luonnehtimani haastattelun aikana haastateltava pyöritteli silmiään, kun kysyin, miksi mielenosoitukseen osallistuminen valtiollisten juhlapyhien aikaan oli pakollista (ote kenttätyöpäiväkirjasta, 4.4.2017). Vaikka tällaiset haastattelukohtaamiset olivat henkisesti raskaita, koin ne oman tutkimuskysymykseni kannalta hedelmällisiksi. Kuten Anna Rastas on monikulttuurisessa kontekstissa tehtyjä etnografisia tutkimushaastatteluja käsittelevässä metodiartikkelissaan huomioinut, kulttuurien välisiä eroja korostava "kulttuuripuhe" liittyy ennen kaikkea rajanvetoihin ja toiseuden tuottamiseen haastateltavan ja haastattelijan välille (Rastas 2005, 84; ks. myös Pietilä 2010, 416). Jäin pohtimaan, miten edellä mainittu haastateltava olisi reagoinut vastaaviin tyhminä pitämiinsä kysymyksiin, jos haastattelijana olisi ollut paikallinen tutkija, joko vastaajan ikäinen ja näin ollen myös Neuvostoliitossa elänyt tai kaltaiseni nuori tutkija, jolla ei olisi omakohtaista kokemusta neuvostotodellisuudesta. Olisiko hän ollut yhtä pöyristynyt "kompakysymyksestä" vai päinvastoin pitänyt sitä perusteltuna päätellen, ettei aiheen varmasti erinomaisesti tunteva tutkija voisi kysyä moista ilman pätevää syytä?

"Ulkopuolisen" haastattelijan asemaan liittyy epäilemättä haasteiden lisäksi myös mahdollisuuksia. Esimerkiksi japanilaisessa kulttuurissa ulkomaalaiselle voi puhua vapaammin kuin oman kansallisuuden edustajalle (Burton 2016, 224). Myös Pietilän mukaan "[u]lkomaalaiselle tutkijalle saatetaan selittää monia asioita yksityiskohtaisemmin, [...] [jonka] seurauksena haastateltavat ryhtyvät eksplikoimaan ja reflektoimaan sellaisia asioita, jotka omasta kulttuurista olevan tutkijan kanssa sivuutettaisiin kaikkien tuntemina itsestäänselvyyksinä." (Pietilä 2010, 415-416.) Hedelmällinen Komsomolin arkipäiväisyyden pohdiskelu ei ollutkaan harvinaista niiden haastateltavien kohdalla, jotka tarttuivat "tyhmiin" kysymyksiini (esim. haastattelu, 25.5.2017).

$7 \quad$ Kysymyksen taustalla vaikutti tosin myös paikallinen akateeminen ympäristö. Valkovenäläisen historiantutkimuksen kontekstissa pelkkä tieteellinen kontribuutio ei ole perusteluna riittävä, vaan tutkimukselta vaaditaan myös käytännön sovellettavuutta. Perustelin tutkimukseni aihetta sillä, ettei Suomessa väitöskirjalla tarvitse välttämättä olla käytännönläheistä käyttötarkoitusta, ja että mielestäni Komsomol-järjestöä ei ollut tutkittu tarpeeksi, varsinkaan valitsemastani näkökulmasta käsittelemälläni aikakaudella. 
Se, että tutkimukseni pyrki saamaan muistitietohaastattelujen avulla tietoa yhteiskunnasta, joka katosi 25 vuotta sitten, tuo myös oman värinsä haastatteluaineistoon. Haastateltavien ryhmän kohdalla nuoruuden ja aikuisuuden välinen raja-aita, ammattiin valmistuminen ja perheen perustaminen, osuu Neuvostoliiton hajoamisen vuosille. 1950-luvulla syntyneet haastateltavat elivät lapsuutensa ja nuoruutensa "pitkän 1970-luvun" Neuvostoliitossa, mutta aikuistuivat Gorbatšovin perestroikan ajalla tai hieman sitä ennen, aikana, johon Valko-Venäjän kontekstissa liittyy myös maan itsenäisyyden puolesta kamppailevan kansanrintaman toiminta. Ero yhtäältä lapsuuden ja nuoruuden sekä toisaalta aikuisuuden välillä näyttäytyi haastateltavien muisteluissa milloin nostalgiana, milloin etäisyyden tunteena. Jokaisessa haastattelussa Komsomol-järjestön toiminta kietoutui kuitenkin osaksi laajempaa nuoruusvuosien kuvausta. Esimerkiksi eräs vastaaja puhui pitkään siitä, kuinka tämä oli löytänyt tyttöystävän Komsomolin järjestämällä patikointileirillä. Vastauksessa korostui nuoruuden ja ensirakkauden huuma, ei niinkään nuorisoliiton järjestötoiminnan konteksti (haastattelu, 7.4.2017). Eräs toinen vastaaja puhui vastaavaan sävyyn ilmeisesti Komsomol-komitean alaisuudessa toimivista musiikki-, tanssi- ja teatteriprojekteista, joihin oli osallistunut (haastattelu, 5.4.2017). Pohdinkin kenttäpäiväkirjassani, voisinko mitenkään "irrottaa" järjestöön liittyviä muistoja esimerkiksi yliopistokontekstissa järjestettävistä muista tapahtumista.

Muisteltava (järjestö)nuoruus saattoi siis tuntua erityisen kaukaiselta, koska haastateltavat viettivät sen niin räikeästi nykyhetkestä eroavissa yhteiskunnallisissa olosuhteissa. Toisin kuin esimerkiksi Suomessa, jossa yhteiskunnallinen muutos on ollut asteittaista, Valko-Venäjällä valtiokommunismin ja Neuvostoliiton murentuminen johti äärimmäisen perustavanlaatuisiin muutoksiin, jotka tapahtuivat vain muutaman vuoden kuluessa. Näiden vuosien aikana myös Komsomolin asema rappioitui: 1980-luvun lopulla ja 1990-luvun alussa nuorisoliittoa arvosteltiin kovin sanoin. Eräs haastateltava kommentoi kritiikkiä "aktiivisena kampanjana, jonka tarkoituksena oli näyttää Komsomol mahdollisimman huonossa valossa". Kampanjan takana olivat hänen mukaansa Neuvostoliiton tuhoa toivoneet länsimaat. (Haastattelu, 16.5.2017.) Myös muut vastaajat olivat tietoisia Komsomolin ryvettyneestä imagosta ja olettivat myös minun omaksuneen kyseisen kuvan järjestöstä. Tämä tietoisuus tuli puettua sanoiksi esimerkiksi näin: "Siitä huolimatta, että Komsomoliin liittyi kieltämättä paljon pahaa, oli järjestössä myös puolensa" (haastattelu, 11.4.2017). Eräs toinen, Komsomol-uralle päätynyt vastaaja, oli selkeästi ottanut tehtäväkseen kertoa kaikesta hyödyllisestä, mitä nuorisoliitto oli aikoinaan tehnyt, luennoiden kansainvälisen kasvatuksen, urheilun, esteettisen kasvatuksen ja isänmaallisuuden teemoista käytännössä koko haastattelun ajan (haastattelu, 24.4.2017). Monologista välittyikin selvästi Pietilän mainitsema "tietynlainen implisiittinen puolustautuminen ulkoa päin esitettäviä syytöksiä vastaan" (Pietilä 2010, 416).

Puolustautumista voi ymmärtää paitsi osana ylikulttuurisen haastattelun dynamiikkaa, myös sen perusteella, että Komsomolin riveissä suoritettuun toimintaan liittyi nykyhetkessä tarkasteltuna - ehkä jo tapahtuma-aikana - tiettyä noloutta. Tämä nolous näkyi siinä, miten haastateltavat raamittivat kerrontaansa huumorin avulla:

Haastateltava: Ai mottoja? Kyllä vain. [Paraatiin] osallistui inmisiä, joiden tehtävänä oli huutaa mottoja kuten “Eläköön Neuvostoliitto!" Meidän tehtävämme oli vastata "Hurraa!" [nauraa]

Haastattelija: Miltä se tuntui?

Haastateltava: Tunsimme olomme idiooteiksi. [nauraa] Varsinkin nuoret, meidät ajettiin sinne kuin lampaat, me kuljimme, meitä manipuloitiin... Totta kai me puhuimme siitä keskenämme, olimme 
hämmentyneitä, teimme siitä pilaa. Mutta tiesimme, että jos sanoisimme jotain, meitä rankaistaisiin heti. (Haastattelu, 24.5.2017.)

Eräs toinen haastateltava kertoi:

Komsomol-aktivisti nousi ja puhui: “Kyllä, tämä henkilö on tosiaan kommunistisen puolueen jäsenyyden arvoinen". Hän puhui pitkään kyseisen henkilön ansioista. Sitten hän istui ja huomautti hiljaa vierustoverilleen "Hän on sellainen liero, että hänet pitää potkia pois Komsomolista” [nauraa] ... Niin puolueen jäsenyyden arvoinen! (Haastattelu, 15.5.2017.)

Komsomol-järjestön toimintaan osallistuminen ei sinänsä ollut stigmatisoivaa tai aiheuttanut häpeää, koska sitä pidettiin osana neuvostoarkielämän absurdiutta, johon osallistuivat kaikki. Toiminnalla ei myöskään ollut mitään todella vakavia seurauksia, jota haastatellut katuisivat nykypäivänä (vrt. Häkkinen ja Salasuo 2015). Tästä huolimatta Komsomolin räikeän poliittisista rituaaleista puhuminen oli haastateltaville jossain määrin vaikeaa, ehkä siksi, että se oli noloudesta huolimatta osa heidän omaa henkilökohtaista menneisyyttään ja nuoruuttaan. Etenkin aineistoanalyysin aikana olen pohtinut, kuinka vapaasti haastateltavat pystyivät omasta mielestään puhumaan aiheesta. Valitettavasti aineistoni ei anna tähän kysymykseen valmiita vastauksia.

\section{Rajoista huolimatta - haastatteludynamiikan universaalit ainekset}

Edellisessä osiossa käsittelin niitä asioita, jotka nousivat esiin ylikulttuurisen muistitietohaastattelun yhteydessä, ja jotka juonsivat juurensa ennen kaikkea Valko-Venäjän paikalliseen ja ajalliseen kontekstiin. Tässä osiossa käsittelen puolestaan niitä erilaisiin valtasuhteisiin linkittyviä seikkoja, jotka luokittelen maa- ja aikakontekstista riippumattomiksi. Muistitietotutkimuksen kentällä etenkin feministisestä tutkimussuuntauksesta ammentavat tutkijat pohtivat aktiivisesti erilaisten valtasuhteiden merkityksiä (ks. esim. Gluck ja Patai 1991). Ylikulttuurinen asetelma tuo kuitenkin ikä- ja sukupuolikategorioihin oman värinsä. Myös tutkimusetiikkaan liittyvät valtasuhdekysymykset ovat ylikulttuurisessa muistitietokontekstissa erityisen tärkeässä roolissa.

Sosiologi Michael Roperin tutkimukseen viitaten Paul Thompson ja Joanna Bornat mainitsevat, että haastattelijan ja haastateltavan välinen ikäero saattaa johtaa tilanteeseen, jossa "itsevarma vanhempi haastateltava kohtelee hyväntahtoisuuttaan haastateltavaa kuin poikaansa, tytärtään tai oppilastaan" (Thompson ja Bornat 2017, 330: Roper 1994). Kuten jo edellä mainitsin, opettaja-oppilas-asetelma oli selkeästi esillä omien haastattelujeni kohdalla. Asetelmaa vahvisti minun ja haastateltavieni noin 30 vuoden ikäeron lisäksi varmasti se seikka, että he mielsivät minun olevan väitöskirjatekijänä heitä, yliopistolehtoreita ja professoreita, alemmassa asemassa akateemisessa hierarkiassa. Valko-Venäjällä erilaiset yhteiskunnalliset hierarkiat ovat esillä vahvemmin kuin Suomessa. Paikalliseen yliopistokulttuuriin esimerkiksi kuuluu, että väitöskirjaa työstävä tohtorikoulutettava on tiukasti väitöskirjaa ohjaavan professorin ohjauksessa. Valko-Venäjällä olisi myös ennenkuulumatonta, että kokeneempi tutkija suhtautuisi väitöskirjantekijään kollegana, mikä ei Suomessa puolestaan ole oman kokemukseni mukaan poikkeuksellista. Haastatteluasetelmaan toi siis oman värinsä se, että haastateltavat kokivat keskustelevansa heitä itseään ammatillisesti kokemattomamman tutkijan kanssa. Ei ollutkaan tavatonta, että koin usein olevani yhtä lailla haastateltavan kuin haastattelijan roolissa keskustelukumppanini tivatessa minulta tutkimukseni yksityiskohdista ja ilmaistessa kriittisyytensä valintojani kohtaan. Kirjoitinkin 
erään vaikean haastattelun jälkeen kenttäpäiväkirjaani: “Yritin kertoa haastateltavalle väitöskirjastani, mutta tunsin oloni naurettavaksi (hän varmaan ajattelee, että olen surkea tutkija ja että tutkimuksessani on huomattavia vikoja)". (Ote kenttätyöpäiväkirjasta, 4.4.2017.) Tämä samoin kuin edellisessä osiossa käsittelemäni kokemus siitä, että olin kysynyt haastateltavalta kysymyksiä, joita tulkitsin heidän pitävän asiantuntemattomina, saattoi hyvin heijastua haastattelutyyliini.

Sukupuolen vaikutuksesta muistitietohaastattelujen valtasuhteille on kirjoitettu paljon. Jotkin tutkijat pitävät "luonnollisena", että naisten on miehiä helpompi haastatella naisia (Gorkin, Pineda ja Leal 2000, 6-7), toisten mielestä se taas voi olla helpompaa miehille (Thompson ja Bornat 2017, 326: Fisher 2006). Omassa tutkimuksessani minulla ei ollut sellaista tunnetta, että sukupuoleni olisi tuottanut automaattisesti "parempia" tai "huonompia" haastattelukokemuksia. Siitä huolimatta koin, että naissukupuoleni yhdistettynä suhteellisen nuoreen ikääni johti helposti asetelmaan, jossa haastattelijat kohtelivat minua "viattomana pikkutyttönä" (ote kenttätyöpäiväkirjasta, 18.4.2017). Vaikka roolissa oli huonot puolensa, koin sen myös mahdollistavan inmettelevien kysymysten esittämisen. Voi myös olla, että tutkimusotteeni olisi saanut haastateltavilta vielä kriittisemmän vastaanoton, jos niitä olisi esittänyt vanhempi mieshenkilö.

Akateemisen aseman sekä iän ja sukupuolen lisäksi kolmas haastattelijan ja haastateltavan valta-asetelmaan liittyvä asia, joka nousi tutkimuksessani selkeästi esille, on muistitietohaastattelun etiikka. Jos ikäni ja sukupuoleni kallistivat minun ja haastateltavieni välistä valta-asemaa jälkimmäisten hyväksi, tutkimuseettisten kysymysten kohdalla vaakakuppi painui epäilemättä minun puolelleni: olinhan, kärjistetysti sanottuna, tullut, haastatellut, ja hävinnyt haastateltavien elämästä heiltä keräämäni materiaalin kanssa. Vaikka haastateltavat antoivat haastatteluun suostumuksensa ja tiesivät, mihin tarkoituksiin heiltä kerättyä materiaalia käytettäisiin, ja vaikka anonymisoin haastattelut heti litterointivaiheessa, tutkimusasetelmaan liittyi myös eettisiä ongelmia. Vaikka tutkimukseni ei varsinaisesti käsitellyt traumaattisia kokemuksia, ainakin kahden vastaajan tunteet nousivat haastattelun aikana pintaan (haastattelut, 12.4.2017 ja 15.5.2017). Toisen haastateltavan kohdalla Komsomol-järjestöajan muistelu toi pintaan kipeitä muistoja isän sairaudesta ja kuolemasta. Toinen puolestaan muisteli katkeruudella Komsomol-toimihenkilöiden julmuutta pakollisten paraatien aikana. En ollut tutkijana varautunut tällaisen tiedon kohtaamiseen, enkä tiennyt, miten minun olisi pitänyt reagoida siihen. Koen myös haasteellisena asetelman, jossa venäjänkieliset haastateltavani eivät välttämättä pysty lukemaan esimerkiksi suomeksi tai englanniksi kirjoittamiani tutkimusartikkeleita. Asiaa ei mielestäni korjaa se, etteivät haastateltavat itse koe kielimuurin olevan ongelma. Kuten Rastas ja Pietilä huomauttavat, monikulttuurisessa kontekstissa tehtävien haastattelujen tulkintavaiheessa tutkijan tulee olla todella varovainen (Rastas 2005, 102; Pietilä 2010, 420). Haastatteluista tehtävien tulkintojen varmistamisen kannalta voi olla ongelmallista, etteivät haastateltavat halua tai voi lukea heidän kertomuksensa pohjalle rakennettua analyysia.

\section{Lopuksi}

Tämän katsauksen tarkoituksena on ollut tuoda uusia näkökulmia monikulttuurisessa kontekstissa tehtäviin historiallisiin muistitietohaastatteluihin. Kun tutkijan uteliaisuutta eivät enää rajoita valtion rajat eivätkä kielimuurit, myös muistitietohaastattelu ylikulttuurisessa kontekstissa kasvattanee suosiotaan entisestään. Ylikulttuurisista haastattelukohtaamisista 
on Suomessa kuitenkin tähän mennessä kirjoitettu lähinnä sosiologian ja etnografian näkökulmasta (Rastas 2005; Pietilä 2010). Tässä katsauksessa olen tarkastellut millaisia haasteita ja mahdollisuuksia ylikulttuuriseen haastatteluun liittyy nimenomaan muistitietotutkimuksen piirissä.

Analyysini kohteena oli kahdentoista muistitietohaastattelun aineistokokonaisuus, jonka keräsin Valko-Venäjällä keväällä 2017. Haastattelun varsinaisen substanssin sijaan analysoin tässä katsauksessa haastattelutilanteiden dynamiikkaa ja pohdin, mitkä tekijät vaikuttivat haastatteluihin ja värittivät niissä tuotettua muistitietoa. Jaottelin haastattelutilanteessa vaikuttaneet tekijät sen mukaan, liittyivätkö ne ennen kaikkea Valko-Venäjään vai olisivatko ne mielestäni voineet nousta esille myös muissa ylikulttuurisissa konteksteissa. Kuten analyysissä kävi ilmi, tekijöillä oli taipumusta kietoutua toisiinsa. Esimerkiksi käsittelemäni Valko-Venäjän historiantutkimuksen kulttuuri ja muistitiedon marginaalinen asema voivat hyvin vallita myös monessa muussa maassa ja ylikulttuurisessa kontekstissa. Lisäksi erikielisyyden tuottaman kuilun käsittely oli tämän aineiston pohjalta vaikeaa, koska haastattelut suoritettiin haastateltavien äidinkielellä, jota puhun itse sujuvasti.

Vaikka katsaus on painottunut monikulttuuriseen muistitietokontekstiin liittyviin haasteisiin, analyysini osoittaa, että ylikulttuurisella lähestymistavalla on paljon annettavaa muistitietotutkimuksen kentällä. "Ulkopuolisena" minua kiehtoivat tutkimusongelmat, joihin paikalliset historiantutkijat eivät ole (ainakaan vielä) kiinnittäneet katsettaan. Haastateltavat olivat myös valmiita selittämään minulle "ulkopuolisena" perinpohjaisesti sellaisia asioita, joita paikalliset tutkijat pitänevät itsestäänselvyyksinä, mikä puolestaan johti hedelmällisiin pohdintoihin tutkimukseni aiheista. Kolmantena seikkana mainittakoon se, että jouduin pohtimaan uudelleen ja uudelleen omaa positiotani tutkijana ja reflektoimaan haastattelutilanteiden kohtaamisten dynamiikkaa. Minusta tuli entistä tietoisempi ajan ja ajallisuuden vaikutuksesta paitsi haastateltavieni myös itseni tuottamissa kertomuksissa.

Vaikka edellä mainitut huomiot ja avaukset nousivat ylikulttuurisesta muistitietotutkimuksen kontekstista, reflektiivinen tutkija voinee tehdä vastaavia huomioita myös haastattelukohtaamisissa, joissa ylikulttuurisuus ei ole läsnä - ainakaan yhtä selkeästi kuin tämän katsauksen esittelemässä tapauksessa.

\section{Lähteet}

\section{Tutkimusaineisto}

Haastattelu 5.4.2017. Minsk. Mies, s. 1950. Rivijäsen.

Haastattelu 7.4.2017. Minsk. Mies, s. 1954. Rivijäsen.

Haastattelu 8.4.2017. Minsk. Nainen, s. 1957. Rivijäsen.

Haastattelu 11.4.2017. Minsk. Mies, s. 1955. Komsomol-toimihenkilö.

Haastattelu 12.4.2017. Minsk. Mies, s. 1951. Rivijäsen.

Haastattelu 24.4.2017. Minsk. Nainen, s. 1952. Komsomol-toimihenkilö.

Haastattelu 26.4.2017. Mahiljeu. Nainen, s. 1955. Rivijäsen. 
Haastattelu 15.5.2017. Mahiljeu. Nainen, s. 1956. Rivijäsen.

Haastattelu 16.5.2017. Minsk. Mies, s. 1958. Komsomol-toimihenkilö.

Haastattelu 17.5.2017. Hrodna. Nainen, s. 1956. Rivijäsen.

Haastattelu 24.5.2017. Hrodna. Mies, s. 1953. Rivijäsen.

Haastattelu 25.5.2017. Minsk. Nainen, s. 1958. Rivijäsen

Kenttätyöpäiväkirja (20.3.-12.6.2017)

\section{Kirjallisuus}

Allison, Fred H. 2004. "Remembering a Vietnam War Firefight: Changing Perspectives over Time." The Oral History Review 31 (2): 69-83. https://doi.org/10.1525/ohr.2004.31.2.69.

Burman, Erica. 1995. "What is it? Masculinity and femininity and the cultural representation of childhood."Teoksessa Feminism and Discourse: Psychological Perspectives, toimittaneet Celia Kitzinger ja Sue Wilkinson, 49-67. London: Sage.

Burton, Susan K. 2016. "Issues in Cross-Cultural Interviewing: Japanese Women in England." Teoksessa The Oral History Reader, toimittaneet Robert Perks ja Alistair Thomson, 223233. London \& New York: Routledge.

Fisher, Kate. 2006. Birth Control, Sex and Marriage in Britain, 1918-1960. New York: Oxford University Press. https://doi.org/10.1093/acprof:oso/9780199267361.001.0001.

Fraser, Ronald. (1979) 1986. Blood of Spain: An oral history of the Spanish Civil War. New York: Pantheon Books.

Gel'man, Vladimir. 2015. "The Politics of Fear: How the Russian Regime Confronts Its Opponents." Russian Politics and Law 53(5-6): 6-26. https://doi.org/10.1080/10611940 .2015 .1146058 .

Gherghina, Sergiu ja Lina Klymenko. 2012. “Why look back? Citizens' attitudes toward the communist regime in Belarus, Russia, and Ukraine." Problems of Post-Communism 59(1): 55-65. https://doi.org/10.2753/PPC1075-8216590105.

Gluck, Sherna Berger ja Daphne Patai. 1991. Women's Words: The Feminist Practice of Oral History. London: Routledge.

Gorkin, Michael, Marta Pineda ja Gloria Leal. 2000. From grandmother to granddaughter: Salvadoran women's stories. Berkeley \& Los Angeles: University of California Press.

Goujon, Alexandra. 2009."Memorial Narratives ofWWII Partisans and Genocide in Belarus."East European Politics and Societies 24(1): 6-25. https://doi.org/10.1177/0888325409355818.

Hirsjärvi, Sirkka ja Helena Hurme. 2008. Tutkimushaastattelu: Teemahaastattelun teoria ja käytäntö. Helsinki: Gaudeamus.

Häkkinen, Antti ja Mikko Salasuo. 2015. "Johdanto." Teoksessa Salattu, hävetty, vaiettu: Miten tutkia piilossa olevia ilmiöitä, toimittaneet Antti Häkkinen ja Mikko Salasuo, 9-17. Tampere: Vastapaino.

Isaikina, Elena. 2011. "Ustav ot VLKSM" ili chto dolzhen znat' budushchiy komsomolets." RIA Novosti 26.9.2011. https://ria.ru/history comments/20110926/443852532.html.

James, Daniel. 2000. Doña María's Story: Life History, Memory, and Political Identity. Durham: Duke University Press.

Kalela, Jorma. 2000. Historiantutkimus ja historia. Helsinki: Gaudeamus. 
Kalela, Jorma. 2006. "Muistitiedon näkökulma historiaan." Teoksessa Muistitietotutkimus: Metodologisia kysymyksiä, toimittaneet Outi Fingerroos, Riina Haanpää, Anne Heimo ja Ulla-Maija Peltonen, 67-92. Helsinki: Suomalaisen Kirjallisuuden Seura.

Koivunen, Pia ja Kari Teräs. 2017. "Historiallinen muistitietohaastattelu." Teoksessa Tutkimushaastattelun käsikirja, toimittaneet Matti Hyvärinen, Pirjo Nikander ja Johanna Ruusuvuori, 193-213. Tampere: Vastapaino.

Korkiakangas, Pirjo. 1996. Muistoista rakentuva lapsuus: Agraarinen perintö lapsuuden työnteon ja leikkien muistelussa. Helsinki: Suomen muinaismuistoyhdistys.

Korkiakangas, Pirjo. 2013. "Onnen aika lapsuuden: Muistelua ja nostalgiaa."Teoksessa Onnen aika? Valoja ja varjoja 1950-luvulla, toimittaneet Kirsi-Maria Hytönen ja Keijo Rantanen, 19-29. Jyväskylä: Atena.

Kozlova, Elena. 2008. "Kak prinimali v Kosmomol: Istoriya pravoi ruki KPSS nachalas' 90 let nazad." Moe! Entsiklopediya voronezhskoi zhizni. http://newspaper.moe-online.ru/ view/15891.html.

Leavy, Patricia. 2011. Oral History: Understanding Qualitative Research. Cary: Oxford University Press. https://doi.org/10.1093/acprof:osobl/9780195395099.001.0001.

Leydesdorff, Selma. 2011. Surviving the Bosnian genocide: The women of Srebrenica speak. Bloomington: Indiana University Press.

Liukkonen, Marjo. 2018. Hennalan naismurhat 1918. Tampere: Vastapaino.

Lintunen, Tiina ja Marko Tikka. 2018. "Miksi Hennalan vankileirin naiset surmattiin? Tuore teos yrittää selvittää vuoden 1918 tapahtumia, mutta tarjoaa totuuden sijasta värittyneitä muistoja." Helsingin Sanomat 29.4.2018.

Mironenko, Viktor. 2000. Komsomol v period perestroiki sovetskogo obshchestva: $v$ poiske novoi modeli soyuza i novoi molodezhnoi politiki (1985 - 1990 gg.). Moskva: Moskovskii gumanitarnyi universitet.

Pietilä, Ilkka. 2010. "Vieraskielisten haastattelujen analyysi ja raportointi." Teoksessa Haastattelun analyysi, toimittaneet Johanna Ruusuvuori, Pirjo Nikander ja Matti Hyvärinen, 411-423. Tampere: Vastapaino.

Pilkington, Hilary. (1994) 2002. Russia's Youth and its Culture: A Nation's Constructors and Constructed. London: Routledge.

Portelli, Alessandro. (1979) 2006. "Mikä tekee muistitietotutkimuksesta erityisen?" Suomentaneet Salla Kivilaakso-Mendes ja Saana Viertomanner. Teoksessa Muistitietotutkimus: Metodologisia kysymyksiä, toimittaneet Outi Fingerroos, Riina Haanpää, Anne Heimo ja Ulla-Maija Peltonen, 49-64. Helsinki: Suomalaisen Kirjallisuuden Seura.

Rastas, Anna. 2005. "Kulttuurit ja erot haastattelutilanteessa." Teoksessa Haastattelu: Tutkimus, tilanteet ja vuorovaikutus, toimittaneet Tarja Aaltonen, Johanna Ruusuvuori ja Liisa Tiittula, 78-102. Tampere: Vastapaino.

Riordan, Jim. 1989. "The Komsomol."Teoksessa Soviet Youth Culture, toimittanut Jim Riordan, 16-44. Houndmills: Macmillan. https://doi.org/10.1007/978-1-349-19932-7 2.

Roper, Michale. 1994. Masculinity and the British Organization Man. Oxford: Oxford University Press.

Shushkevich, Stanislav. 2002. Neo-Communism in Belarus. Smolensk: Skif. 
Summerfield, Penny. 2004. "Culture and Composure: Creating Narratives of the Gendered Self in Oral History Interviews." Cultural and Social History 1(1): 65-93.

Thompson, Paul ja Joanna Bornat. 2017. The voice of the past: Oral history. 4th edition. New York. Oxford University Press.

Tkachenko, Viktor. 2011. "Komsomol v period perestroiki." Izvestiya Volgogradskogo gosudarstvennogo pedagogicheskogo universiteta 57(3): 97-100.

Ukkonen, Taina. 2006. "Yhteistyö, vuorovaikutus ja narratiivisuus muistitietotutkimuksessa." Teoksessa Muistitietotutkimus: Metodologisia kysymyksiä, toimittaneet Outi Fingerroos, Riina Haanpää, Anne Heimo ja Ulla-Maija Peltonen, 175-198. Helsinki: Suomalaisen Kirjallisuuden Seura.

Vehkalahti, Kaisa. 2014. "Muisteltu ja kerrottu nuoruus 1920- ja 1930-luvulla syntyneiden omaelämäkerrallisissa teksteissä." Teoksessa Nuoruuden sukupolvet: Monitieteisiä näkökulmia nuoruuteen eilen ja tänään, toimittaneet Kaisa Vehkalahti ja Leena Suurpää, 5-29. Helsinki: Nuorisotutkimusverkosto.

Yow, Valerie. 2016. "Interviewing Techniques and Strategies." Teoksessa The Oral History Reader, toimittaneet Robert Perks ja Alistair Thomson, 153-178. London \& New York: Routledge.

Yurchak, Alexei. 2006. Everything Was Forever, Until It Was No More: The last Soviet generation. Princeton, NJ: Princeton University Press.

MA Kristiina Silvan työskentelee väitöskirjatutkijana Helsingin yliopistossa. Hänen poliittisen historian väitöskirjansa käsittelee valtiollisia nuorisojärjestöjä Venäjällä ja Valko-Venäjällä. 